\title{
Circumcaval ureter/retrocaval ureter
}

\author{
Samarth Agarwal, ${ }^{1}$ Sunny Goel, ${ }^{1}$ Satyanarayan Sankhwar, ${ }^{2}$ Gaurav Garg ${ }^{1}$
}

'Department of Urology, King George's Medical University, Lucknow, Uttar Pradesh, India ${ }^{2}$ Department of Urology, CSM Medical University (Upgraded KGMC), Lucknow, Uttar Pradesh, India

\section{Correspondence to} Dr Samarth Agarwal, rebellite@gmail.com

Accepted 29 May 2018

\section{DESCRIPTION}

A 33-year-old non-diabetic married woman from rural background presented with complaints of dull intermittent right flank pain since 1 year. She had no history of fever, dysuria, haematuria or weight loss. Clinical examination of the abdomen was within normal limits. Complete laboratory evaluation including urinalysis, complete blood picture, urea, creatinine and electrolytes were within normal limits. Ultrasonography (USG) of kidney, ureters and bladder showed moderate hydroureteronephrosis (HDUN) until right midureter. Intravenous pyelography (IVP) revealed dilated right renal pelvicalyceal system and upper ureter with abrupt S-shaped turn of ureter at the level of L4 vertebrae.

The appearance on IVP was strongly suspicious of retrocaval ureter and hence a contrast-enhanced CT urography was performed to confirm the diagnosis, which showed dilated right proximal ureter (figure 1) coursing medially and lying posterior to inferior vena cava (IVC). Three-dimensional reconstruction from CT urography showed proximal HDUN and classical S-shaped loop of the ureter behind the IVC (figure 2).

Diuretic renal scan (Tc-99m diethylene-triamine-penta-acetic acid) showed reduced right renal function with obstructed, hydroureteronephrotic drainage. After informed consent of the patient was taken, a right ureteroureterostomy was performed after mobilising ureter anterior to IVC.

Retrocaval ureter is also known as circumcaval ureter. It is a term used to describe an abnormal

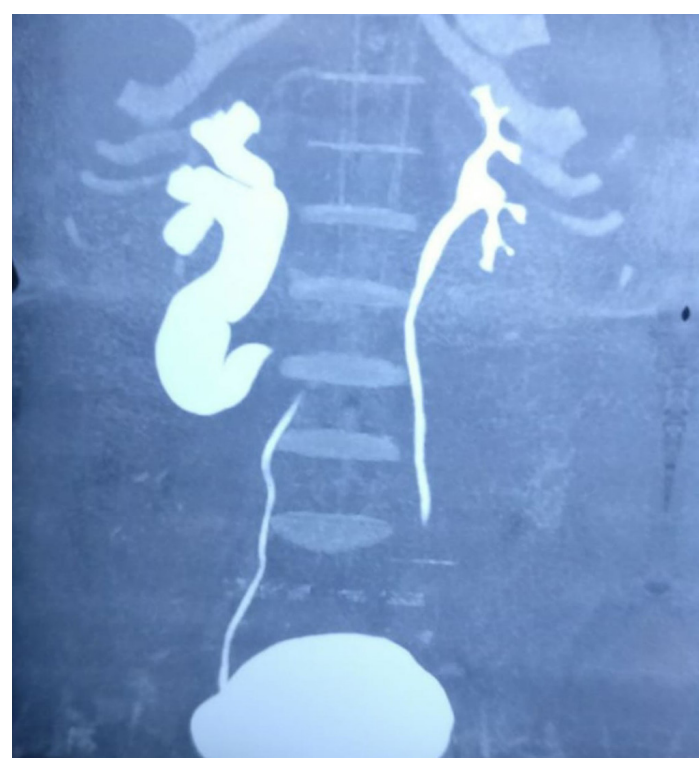

Figure $1 \mathrm{CT}$ urography of 33-year-old woman showing right retrocaval ureter.

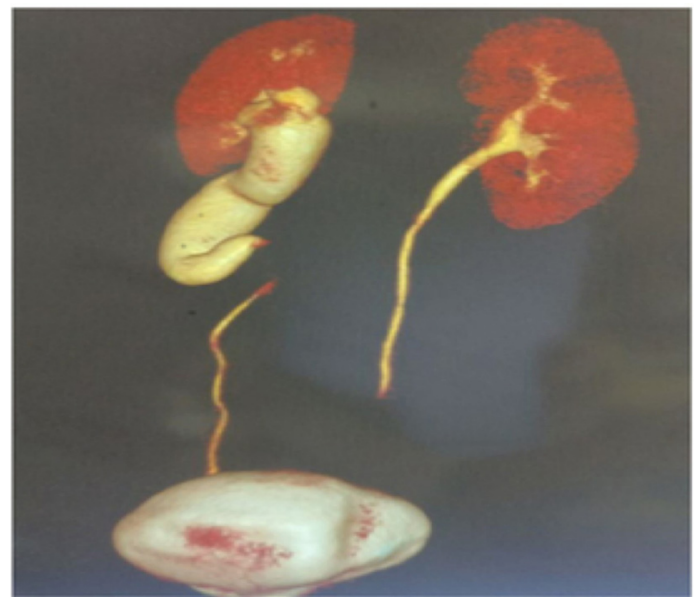

Figure 2 Reconstruction image of the same patient showing proximal $\mathrm{h}$ ydroureteronephrosis and classical $\mathrm{S}$-shaped loop of the ureter behind the inferior vena cava.

course of a ureter that encircles the IVC. Both of these terms are somewhat misleading, as this configuration is considered a developmental anomaly of the IVC.

It results from abnormal persistence of right subcardinal vein ventral to ureter during embryogenesis of IVC. The developing right ureter courses behind and medial to IVC over pedicle of L3-L4 vertebrae then exits between IVC and aorta returning to its normal position. This produces varying degree of HDUN. ${ }^{12}$

The overall incidence of retrocaval ureter is $0.07 \%$ with male to female ratio of $3: 1$.

Most patients are asymptomatic with most common presenting feature being flank pain and/ or recurrent urinary tract infections due to urinary stasis.

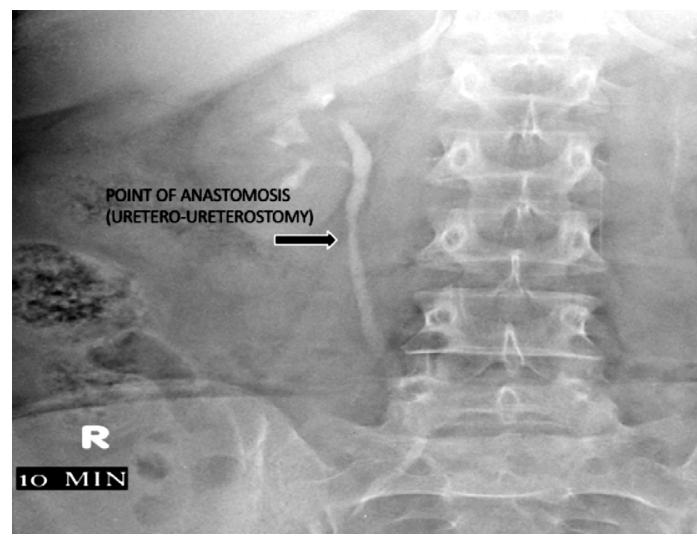

Figure 3 Postoperative intravenous pyelography film done after 6 months showing point of anastomosis and complete resolution of hydroureteronephrosis. 
Retrocaval ureters are classified into two clinical types. Type 1 is the most common and has moderate to severe hydronephrosis in about $50 \%$ of cases with extreme medial deviation of middle ureteric segment and the ureter assuming an S or 'fish hook' deformity.

Type 2 has less medial deviation of the ureter with mild or no associated hydronephrosis and forms about $10 \%$ of cases. Surgical management is reserved for the type 1 cases that are usually symptomatic as was in this case. ${ }^{12}$

In this case treatment was surgical and involved division of the ureter and repositioning it anterior to the IVC. This was achieved through a ureteroureteric anastomosis over a double-J stent. The segment behind the IVC was aperistaltic and excised.

\section{Learning points}

- Retrocaval ureter is a rare entity.

- Most patients are asymptomatic. However, symptomatic patients warrant surgical treatment.

- Ureteroureterostomy with anterior repositioning of ureter is curative in most cases.
An IVP was performed at 6 months (figure 3), and it showed complete resolution of HDUN.

A repeat USG and diethylenetriaminepentaacetic acid (DTPA) scan performed at 6 months also showed minimal hydronephrosis (HDN) of right kidney with no complaints of pain.

Contributors SA: concept, design, supervision, processing and writing manuscript and critical analysis. SG: concept, design, supervision and processing. SS: concept, supervision, writing manuscript and proofreading. GG: proofreading, editing and critical analysis.

Funding The authors have not declared a specific grant for this research from any funding agency in the public, commercial or not-for-profit sectors.

Competing interests None declared.

Patient consent Obtained.

Provenance and peer review Not commissioned; externally peer reviewed.

(C) BMJ Publishing Group Ltd (unless otherwise stated in the text of the article) 2018. All rights reserved. No commercial use is permitted unless otherwise expressly granted.

\section{REFERENCES}

1 Kenawi MM, Williams DI. Circumcaval ureter: a report of four cases in children with a review of the literature and a new classification. Br J Urol 1976;48:183-92.

2 Bateson EM, Atkinson D. Circumcaval ureter: a new classification. Clin Radiol 1969;20:173-7.

Copyright 2018 BMJ Publishing Group. All rights reserved. For permission to reuse any of this content visit

http://group.bmj.com/group/rights-licensing/permissions.

BMJ Case Report Fellows may re-use this article for personal use and teaching without any further permission.

Become a Fellow of BMJ Case Reports today and you can:

- Submit as many cases as you like

- Enjoy fast sympathetic peer review and rapid publication of accepted articles

- Access all the published articles

Re-use any of the published material for personal use and teaching without further permission

For information on Institutional Fellowships contact consortiasales@bmjgroup.com

Visit casereports.bmj.com for more articles like this and to become a Fellow 